Article

\title{
Current Status and Future Directions in Modeling a Transboundary Aquifer: A Case Study of Hueco Bolson
}

\author{
Rocky Talchabhadel ${ }^{1, * \mathbb{D}}$, Helene McMillan ${ }^{1}$, Santosh S. Palmate ${ }^{1} \mathbb{D}$, Rosario Sanchez ${ }^{2}$, Zhuping Sheng ${ }^{1,+}$ \\ and Saurav Kumar $1, *$ (D) \\ 1 Texas A\&M AgriLife Research, Texas A\&M University, El Paso, TX 79927, USA; \\ helene.mcmillan@ag.tamu.edu (H.M.); santosh.palmate@ag.tamu.edu (S.S.P.); zsheng@yahoo.com (Z.S.) \\ 2 Texas Water Resources Institute, Texas A\&M University, 1500 Research Parkway, MS 2260, \\ College Station, TX 77845, USA; Rosario@tamu.edu \\ * Correspondence: rocky.talchabhadel@ag.tamu.edu (R.T.); saurav@tamu.edu (S.K.) \\ + Retired.
}

check for updates

Citation: Talchabhadel, R.; McMillan, H.; Palmate, S.S.; Sanchez, R.; Sheng, Z.; Kumar, S. Current Status and Future Directions in Modeling a Transboundary Aquifer: A Case Study of Hueco Bolson. Water 2021, 13, 3178. https://doi.org/10.3390/ w13223178

Academic Editors: Sharon B. Megdal and Anne-Marie Matherne

Received: 1 July 2021

Accepted: 4 November 2021

Published: 10 November 2021

Publisher's Note: MDPI stays neutral with regard to jurisdictional claims in published maps and institutional affiliations.

Copyright: (c) 2021 by the authors. Licensee MDPI, Basel, Switzerland. This article is an open access article distributed under the terms and conditions of the Creative Commons Attribution (CC BY) license (https:// creativecommons.org/licenses/by/ $4.0 /)$.
Abstract: The Hueco Bolson aquifer is a binational aquifer shared by the United States of America (USA) and Mexico that is strongly interconnected with the transboundary river, Rio Grande/Rio Bravo. Limited recharge, increasing urbanization, and intensified agriculture have resulted in the over-drafting of groundwater resources and stressed the aquifer, threatening its sustainability if mitigation actions are not taken soon. Research indicates that the aquifer's hydraulic gradients and flow directions have changed due to the high groundwater withdrawal rates from the two major cities-El Paso (USA) and Ciudad Juarez (Mexico). This paper presents a comprehensive overview of the Hueco Bolson aquifer modeling history and makes a case for future modeling and binational engagement efforts. First, we discuss the evolution of groundwater modeling for Hueco Bolson from the past to recent times. Second, we discuss the main water management issues in the area, including water quality and quantity, stakeholders' participation, and climate change. To address the challenges of holistic water management, we propose developing a graphical quantitative modeling framework (e.g., system model and Bayesian belief network) to include experts' opinions and enhance stakeholders' participation in the model. Though the insights are based on a case study of Hueco Bolson, the approaches discussed in this study can provide new strategies to overcome the challenges of managing a transboundary aquifer.

Keywords: groundwater; Hueco Bolson; MODFLOW; Rio Grande; transboundary aquifer

\section{Introduction and History of Modeling Efforts}

An aquifer is considered transboundary if it is part of a "system of surface water and groundwater situated in more than one nation" [1]. This applies when (i) an internal groundwater body is hydraulically connected to a transboundary river and (ii) a domestic river is interlinked to a transboundary aquifer [2]. For the Rio Grande-Hueco Bolson (Rio Bravo-Valle de Juarez) water system (Figure 1a), both are the case. The USA-Mexico international border follows the Rio Grande river course above the Hueco Bolson aquifer, and the internal aquifer stretches into the USA and Mexico. The Hueco Bolson lies within the state-triangle of New Mexico (USA), Texas (USA), and Chihuahua (Mexico) and is recognized as a transboundary aquifer by the USA and Mexico [3,4]. It has been declared a priority aquifer under the Transboundary Aquifer Assessment Program (TAAP) [5] of the USA and Mexico, highlighting the importance of Hueco Bolson for the transboundary Paso del Norte Region with its sister cities of El Paso (Texas) and Ciudad Juarez (Chihuahua).

The first hydrogeological studies of the Hueco Bolson were carried out by Slicher [6] and Richardson [7] in the early 1900s when significant pumping of the Hueco Bolson started. The first pump field, the Old Mesa field, was developed in 1904 [8]. Water withdrawal steadily increased until the 1950s, which triggered comprehensive studies 
about the geology, hydrogeology, and the groundwater resources of the El Paso area by the United States Geological Survey (USGS) [9,10], and has since accelerated due to the rapid population growth of the Paso del Norte Region [8]. In 2020, the combined sister cities had a population of approximately 2.2 million people, i.e., Ciudad Juarez with 1.51 million [11] and El Paso with 0.68 million [12]. Large water consumers of the region entirely rely on the Hueco Bolson as their drinking water supply, including the U.S. Army Air Defense Artillery Center Fort Bliss and several small communities [13]. Ciudad Juarez uses the Hueco Bolson as its main source for potable water [4], and El Paso Water (EPW, used to be called El Paso Water Utilities) relies on groundwater for approximately $40 \%$ of its total water supply in an average non-drought year-and this number is higher in drought years [14]. In addition, agriculture in the Paso del Norte Region depends on irrigation. In non-drought years, enough water is released from the Elephant Butte Reservoir (Figure 1a) into the downstream Rio Grande, and irrigation water demands can mainly be covered by surface water. However, groundwater must be pumped to meet the irrigation water demand in dry years [15].

White [8] estimated that approximately 40 million $\mathrm{m}^{3}$ of water per year is recharged into the Rio Grande alluvium overlying the Hueco Bolson aquifer, which is far less than the withdrawal [16]. As the aquifer only receives such limited recharge in terms of rainfall, seepage or/and artificial deep-well injection and infiltration basins $[13,17,18]$, the longterm mining of the Hueco Bolson resulted in a significant groundwater drawdown and decreased the water quality at some locations. The large water-level declines changed the groundwater flow directions since the 1960s $[8,19]$ and caused flow intrusion from surrounding brackish water into the freshwater zone $[13,20]$. Proactive management strategies, mainly carried out by the EPW, include reducing per capita water use [21] and artificial aquifer recharge [18] to reduce freshwater pumping and slow down brackish water intrusion. In recent years, several projects (Table 1) have been carried out and contributed to a better understanding of the current situation of the Hueco Bolson.

Table 1. List of major groundwater models of the Hueco Bolson.

\begin{tabular}{|c|c|c|}
\hline Key Findings & Study & Year Published \\
\hline $\begin{array}{l}\text { Saline water resources in Hueco Bolson using a two-dimensional } \\
\text { electric-analog model for 1903-1963 }\end{array}$ & Leggat and Davis [22] & 1967 \\
\hline $\begin{array}{l}\text { A two-layered digital model of the Hueco Bolson from } 1903 \text { to } 1973 \\
\text { using a computer program developed by Bredehoeft and Pinder [23] }\end{array}$ & Meyer [24] & 1976 \\
\hline $\begin{array}{c}\text { Report 3-Hydrogeology of the Hueco Basin: Prepared for thePublic } \\
\text { Services Board, City of El Paso, Texas }\end{array}$ & Lee Wilson and Associates [25] & 1985 \\
\hline $\begin{array}{l}\text { Summary of U.S. Geological Survey ground-water-flow models of } \\
\text { basin-fill aquifers in the southwest alluvial basins' region, Colorado, } \\
\text { New Mexico, and Texas }\end{array}$ & Kernodle [26] & 1992 \\
\hline $\begin{array}{l}\text { Simulation of groundwater and saline water in Hueco Bolson aquifer } \\
\text { using the modular model developed by McDonald and Harbaugh [27] } \\
\text { and solute transport three-dimensional flow model developed by } \\
\text { Kipp [28] }\end{array}$ & Groschen [29] & 1994 \\
\hline $\begin{array}{l}\text { Groundwater model using a modified version of MODFLOW } 96 \\
\text { developed by Harbaugh and McDonald [30]; the model was simulated } \\
\text { from } 1903 \text { to } 1996\end{array}$ & Heywood and Yager [31] & 2003 \\
\hline $\begin{array}{l}\text { The MODFLOW model was updated to include input data from } 1997 \\
\text { to } 2002\end{array}$ & Hutchison [32] & 2004 \\
\hline $\begin{array}{l}\text { Groundwater Flow for Administration and Management in the Lower } \\
\text { Rio Grande Basin. Main Report; Technical Report prepared for the State } \\
\text { of New Mexico }\end{array}$ & Papadopoulos and Associates [33] & 2007 \\
\hline $\begin{array}{l}\text { Updated model for Hueco Bolson aquifer using MODFLOW-2005 and } \\
\text { MT3DMS solute transport code }\end{array}$ & Hutchison $[34,35]$ & 2016 \\
\hline
\end{tabular}


Eastoe et al. [36,37] showed that surface water from the Rio Grande infiltrated far deeper into the groundwater body before the Elephant Butte Dam was constructed than after its construction in 1916. The groundwater chemistry and isotope study of Anderholm and Heywood [38] indicated that the infiltration of precipitation and the runoff from the Franklin Mountains is the main source of groundwater along the ridge, and dilute recharge water mixes with sodium chloride brine as groundwater moves away from the recharge area. The location of fresh and brackish groundwater seems to be controlled by stratigraphic and structural changes in the El Paso area of the Hueco Bolson [39]. In some parts of the basin, the deeper-lying saline groundwater [32] can upwell through fractures due to fault step-overs [39]. Effects of the surrounding land-use activities, i.e., agriculture and wastewater treatment systems, are reflected in the lower groundwater quality near the Rio Grande than farther away from the river [40].

The first study that conducted groundwater modeling across the Hueco Bolson was by Leggat and Davis [22] in 1967, using an electric-analog approach (refer to Table 1 for some major studies). Groundwater modeling became more user-friendly after USGS published MODFLOW-96 with several graphical interfaces. The latest model, to our knowledge, was commissioned by EPW [34], which is a groundwater model developed with MODFLOW2005 which concentrated on developing a conjunctive use strategy for surface water and groundwater supplies and locating the production wells for the Kay Bailey Hutchinson Desalination Plant. The model also includes a chloride transport model using the MT3DMS (Modular 3-D Multi-Species Transport model) solute transport code [34].

The management of an aquifer, particularly a transboundary aquifer, is a social enterprise that needs cooperation among stakeholders [41,42]. The numerical models developed should enable such cooperation by providing robust unbiased results and promoting education and intuition building for all stakeholders whose partnership is sought. We propose that quantitative graphical models such as the Bayesian belief network (BBN) and system modeling may be necessary in addition to the numerically intensive physically based models.

\section{Physical Setting, Data, and Numerical Modeling}

The Hueco Bolson is located in the border triangle of Far West Texas, southern New Mexico, and northern Chihuahua (Figure 1a). It covers approximately $6500 \mathrm{~km}^{2}$ with approximately $2 / 3$ lying in the USA and $1 / 3$ lying in Mexico, the Hueco Mountain range in the east, and the Sierra Juarez Mountain range in the south. In the North, the Hueco Bolson borders the Tularosa Basin (Figure 1a). This boundary between the two aquifers is not geological or hydrogeological, as they are hydraulically connected but have already been divided by Richardson [7]. This study only covers the heavily pumped Hueco Bolson. For modeling purposes, the hydraulic connection between Hueco Bolson and the Tularosa Basin will be represented as inflow at the northern boundary.

The climate in the Chihuahuan Desert is arid with an average annual precipitation of $253 \mathrm{~mm}$ and potential evapotranspiration of $1773 \mathrm{~mm}$ based on Climate Research Unit (CRU) gridded time series from the recent 30 years [43]. The Rio Grande flow depends on mountain snowpack runoff, upstream water diversions, reservoir releases, as well as agricultural and urban return flows. The river flows below Caballo Reservoir are managed by releasing the water from two reservoirs (i.e., Elephant Butte and Caballo). Most of the precipitation occurs as rainfall during the monsoon season from June to September. Generally, the sparse rainfall over the basin floor outside the Rio Grande Valley evaporates or transpires from the vadose zone before it can infiltrate water-table depths and recharge the aquifer system. Applied irrigation water has a better chance of infiltrating the water table because the water table is within several meters of the land surface in the Rio Grande Valley and flood irrigation is dominant in the region [31]. Pecans and cotton are the dominant crops, and gravel, fine sandy loam, and loamy fine sands are predominant soil types [34]. 
a)

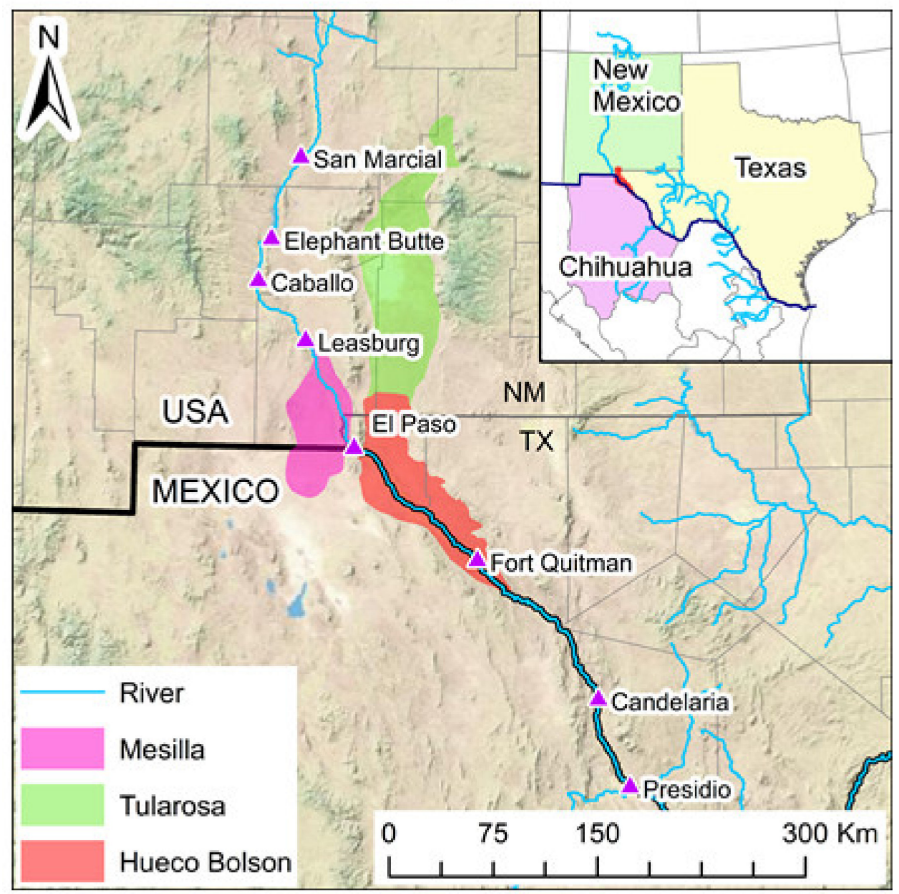

b)
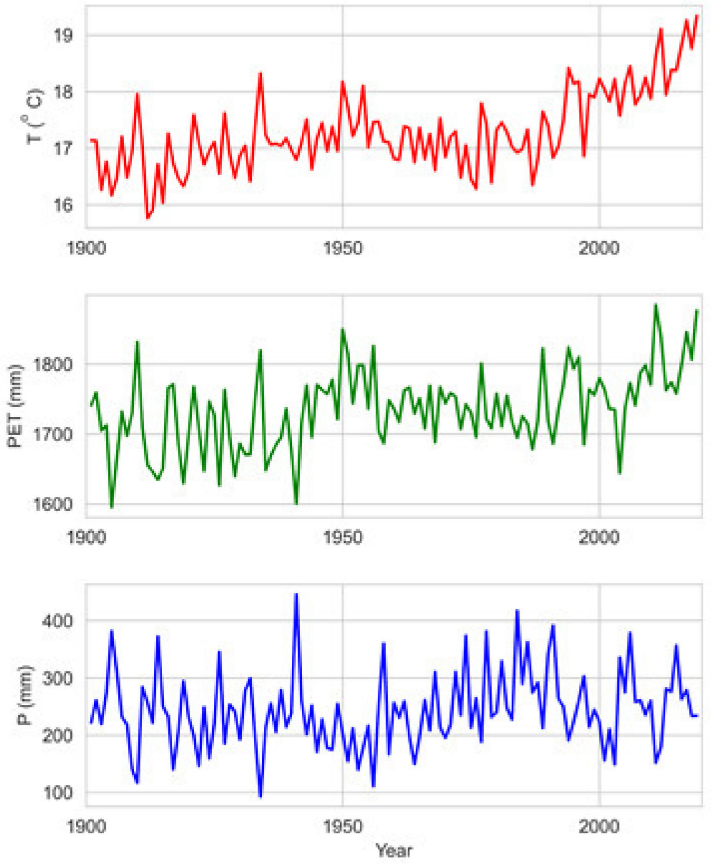

Figure 1. (a) Map showing Hueco Bolson and the adjacent Mesilla and Tularosa aquifers overlaid over administrative borders and the river channel. Triangles are streamflow gauging stations. Elephant Butte and Caballo are two reservoirs controlling the release of streamflow. Inset shows the Hueco Bolson aquifer (red), located in two states of the USA states (Texas and New Mexico) and the state of Chihuahua, Mexico; and (b) the inter-annual variation in average temperature (T), potential evapotranspiration (PET), and precipitation (P) from 1901 to 2019 across the Hueco Bolson [43].

\subsection{Geology and Hydrogeology}

The Hueco Bolson follows the structural depression associated with the Rio Grande Rift. The northern part is dominated by north striking faults, whereas the southern part, mainly located in Mexico, is characterized by northwest-striking faults [39]. The main aquifer is of unconfined and semiconfined nature and consists of basin-fill deposits up to $2500 \mathrm{~m}$ thickness [10]. It is commonly divided into hydrogeologic unit-alluvial facies, alluvial-fan facies, lacustrine-playa facies, and recent alluvial facies [31]. The deeper layers are Tertiary age deposits, whereas the recent alluvial facies are considered Quaternary and along the Rio Grande [31]. The freshwater body of Hueco Bolson is surrounded by naturally occurring brackish and saline groundwaters (>1000 TDS) [17]. Freshwater is mainly present on the west side of the Hueco Bolson at a depth of $320 \mathrm{~m}$ and more [44]. Towards the east, salinity levels increase, and the freshwater layer thins to less than $30 \mathrm{~m}$ [19]. Groundwater chemistry analysis by EPW showed a salinity increase with depth, and TDS values were measured as high as $35,000 \mathrm{mg} / \mathrm{L}$ [17].

\section{Groundwater Observations}

Figure 2a shows a monthly variation of groundwater pumping from the Hueco Bolson in the USA and Mexico regions from 1969 to 2013. The figure shows a substantial monthto-month variation. There is a clear indication of a sharp rise in groundwater pumping in Mexico until the year 2000 (from 2 million $\mathrm{m}^{3}$ per month in 1969 to approximately 12 million $\mathrm{m}^{3}$ per month in 2000). In contrast, the temporal evolution of groundwater pumping in the USA shows a less obvious trend. However, a mild rising trend of groundwater pumping in the USA from 1969 to 1990 (from approximately 7 million $\mathrm{m}^{3}$ per month in 1969 to approximately 8.5 million $\mathrm{m}^{3}$ per month in 1990) is observed, followed by a sharp declining trend until 2000. The non-parametric rank-based Mann-Kendall method [45,46], in conjunction with the Theil-Sen slope method $[47,48]$, showed a statistically significant 
declining trend at a significance level of $99 \%$ for all months (January to December) in Mexico from 1969 to 2013. In contrast, there is a mixed pattern of increasing, decreasing, and no trends (statistically significant and non-significant) in the USA. We computed the trend magnitude and significance using the pyMannKendall package [49] following Yue and Wang's [50] pre-whitening method to limit the serial correlation contaminated in the observation time series [51]. We observe that the average monthly rise in groundwater pumping in Mexico is approximately 3 million $\mathrm{m}^{3}$ per month per decade, which varies from approximately 2.2 million $\mathrm{m}^{3}$ per month per decade in February to approximately 3.5 million $\mathrm{m}^{3}$ per month per decade in July. In comparison, there is no clear tendency in the USA. Additionally, the temporal fluctuation is low compared to Mexico. However, with a noticeable oscillation, there has been an increasing trend of groundwater pumping since 2009 in the USA.

a)

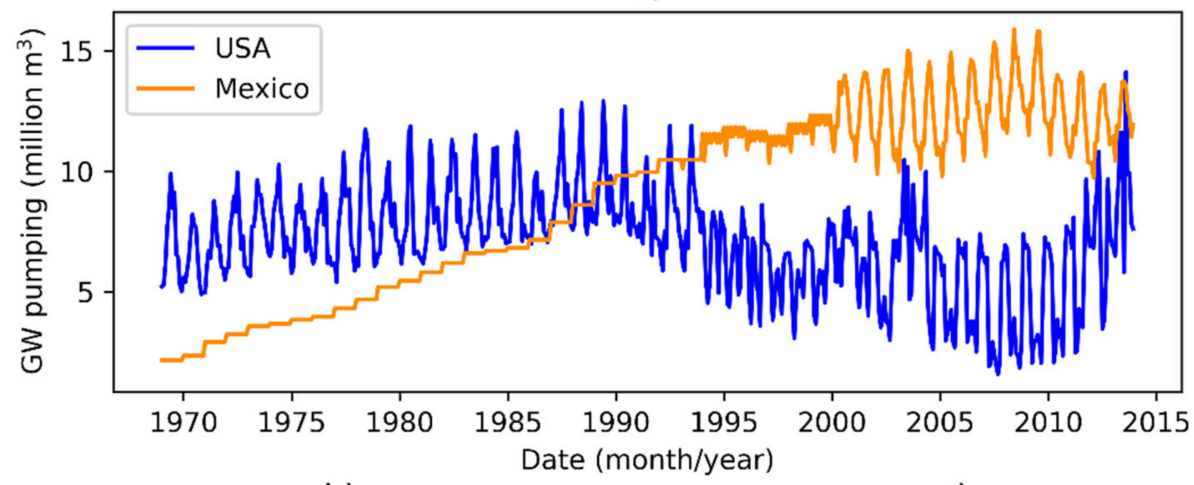

b)
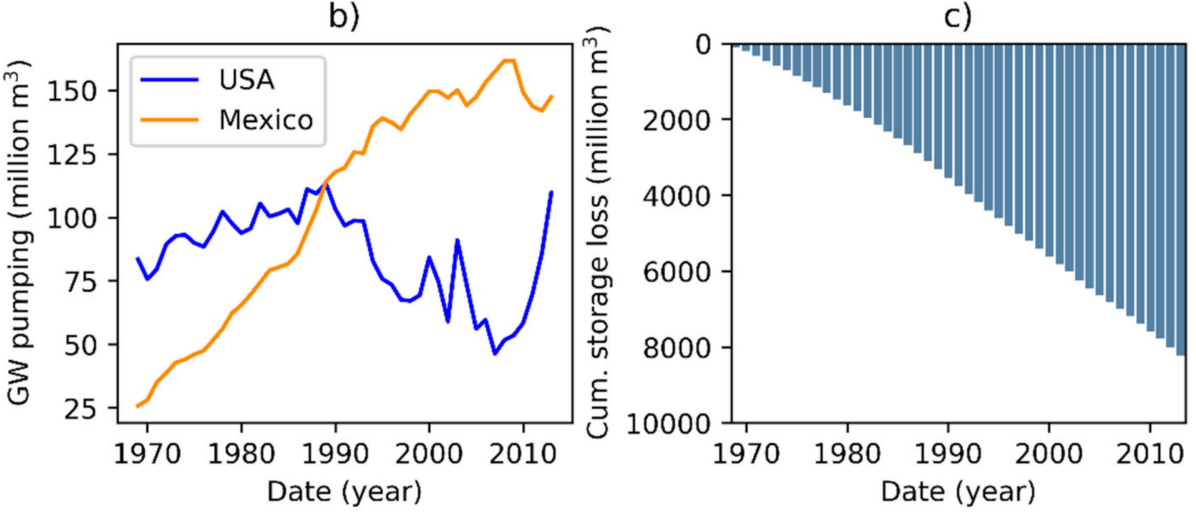

Figure 2. (a) Temporal variation in monthly total groundwater (GW) pumping in USA (average value of 346 wells) and Mexico (average value of 266 wells); (b) yearly variation of GW pumping in USA and Mexico. Daily data from these wells were used to compute monthly and annual total GW pumping; and (c) cumulative storage loss from the aquifer with respect to the initial year taken in this study (1969). Note: bars are inverted here to represent storage loss.

Overall, the rising groundwater withdrawal raises a question on the sustainability of water availability of the Hueco Bolson aquifer. Figure $2 \mathrm{~b}$ shows the temporal variation in annual total groundwater pumping in the USA and Mexico. The annual groundwater pumping in Mexico steadily increased from approximately 25 million $\mathrm{m}^{3}$ in 1969 to approximately 150 million $\mathrm{m}^{3}$ in 2013. Figure 2c informs the aquifer's cumulative storage loss with respect to the initial year taken here as 1969. These observations provide an insight into the stress of the aquifer. However, numerical modeling would explain the local and regional groundwater dynamics and provide a spatiotemporal distribution of the hydraulic heads. Therefore, we aimed to numerically simulate the historical groundwater dynamics and explore the possible stress under climate change and different groundwater pumping scenarios. 
Similarly, based on the ground-based observed data from nine stations from 1998 to 2013, we found that the TDS values of river water were higher downstream during both irrigation and non-irrigation periods. For example, the average TDS value in Fort Quitman, located $120 \mathrm{~km}$ south of El Paso, was approximately $2000 \mathrm{mg} / \mathrm{L}$-almost double the average for the El Paso area. Additionally, the average TDS values in the dry year (2003, annual precipitation $=135 \mathrm{~mm}$ ) were over $10 \%$ higher than during the wet year $(2007$, annual precipitation $=360 \mathrm{~mm}$ ). In addition to hydroclimatic factors, the soil salinity levels of upland soils are directly associated with soil texture, permeability, and irrigation. The salts in the soils are brought in either through irrigation or have a geological origin. The soil textures across the selected study area show that sand and cobble dominate near the El Paso gauge, whereas loam and silty loam dominate Fort Quitman.

In the early 20th century, before the impact of major groundwater pumping on both sides of the border occurred, the general groundwater flow was south from the TexasNew Mexico line and east to southeast from the Sierra de Juarez toward the valley of Rio Grande [8]. As a result, underflows across the political boundaries were from Mexico to the USA, enhanced by increased groundwater withdrawal from El Paso and an even larger hydraulic gradient from south to North [13]. However, the net flow has reversed since the 1960s due to increased pumping in Ciudad Juarez [19]. Groundwater level declines are sharp in downtown areas of El Paso and Ciudad Juarez. Cones of depression are formed at these pumping centers, which affect the flow patterns. Heavy pumping decreases hydraulic heads and induces the movement of surrounding saline water into the freshwater zone. TDS values of pumped groundwater have increased for more than 70 years and even necessitate well abandonment in the El Paso area [31]. Ashworth [52] suggested that the annual increase in salinity was approximately $10-30 \mathrm{mg} / \mathrm{L}$ per year from the $1950 \mathrm{~s}$ to 1990 , and in parts of downtown El Paso and Ciudad Juarez, an annual increase of 40 to $100 \mathrm{mg} / \mathrm{L}$ per year was observed. For the years after 1979, Sheng [19] observed an annual rise of 80 to $120 \mathrm{mg} / \mathrm{L}$ per year at some locations. This indirect reduction in the fresh groundwater resource especially occurred in the wellfields near the El Paso Airport and northeast of El Paso $[13,44]$.

\subsection{Numerical Modeling}

Numerical modeling for the Hueco Bolson Aquifer has been largely based on the MODFLOW. MODFLOW solves the groundwater flow equation using linear and nonlinear numerical solution methods [53]. The first MODFLOW model was initially developed by Heywood and Yager [31] in MODFLOW 96 over the larger Rio Grande area, including the Hueco Bolson aquifer (Table 1). The Heywood and Yager Hueco Bolson aquifer model [31] consists of ten layers of 165 rows and 100 columns in a variable grid, with the finer grid in El Paso and Juarez area [54]. The model was calibrated with data from 1903 to 1996. It was later upgraded to MODFLOW 2000 and then to MODFLOW 2005 [55]. The packages included in the MODFLOW model are: well packages, multi aquifer well packages stream package, drain package, evapotranspiration package, recharge package, horizontal flow barrier, and flow and head boundary package [56]. EPW then updated the model to include input data from 1997 to 2002 [32]. We used the EPW model and developed the current MODFLOW model for Hueco Bolson.

\subsubsection{Current MODFLOW Model}

The latest model developed for the area of interest has a ten vertical-layers grid. The top nine layers are $30 \mathrm{~m}$ thick and the bottom layer is $276 \mathrm{~m}$ thick (Figure $3 \mathrm{c}, \mathrm{d}$ ). The first $30 \mathrm{~m}$, i.e., the top layer, is set as alluvial deposits and the other remain as fluvial facies. The horizontal domain is represented with rectangular grids (Figure 3a). We simulated monthly water stress from 1969 to 2013. Groundwater levels measured at wells and pumping data were used to calibrate the model. The inflow boundary condition was set in New Mexico (shown in green in Figure 3b). Similarly, the outflows from the USA and Mexico were placed at the southeast corner (shown in blue and brown, respectively, in Figure 3b). 
Accurate boundaries of aquifers are hard to establish, especially for the connected aquifers (e.g., Hueco-Tularosa). Although no clear physical boundary separates the Hueco Bolson from the Tularosa basin, the recognized Hueco Bolson aquifer (Figures 1a and 3a) does extend to New Mexico [31]. In the USA, groundwater in a shared aquifer is managed by each state [19].

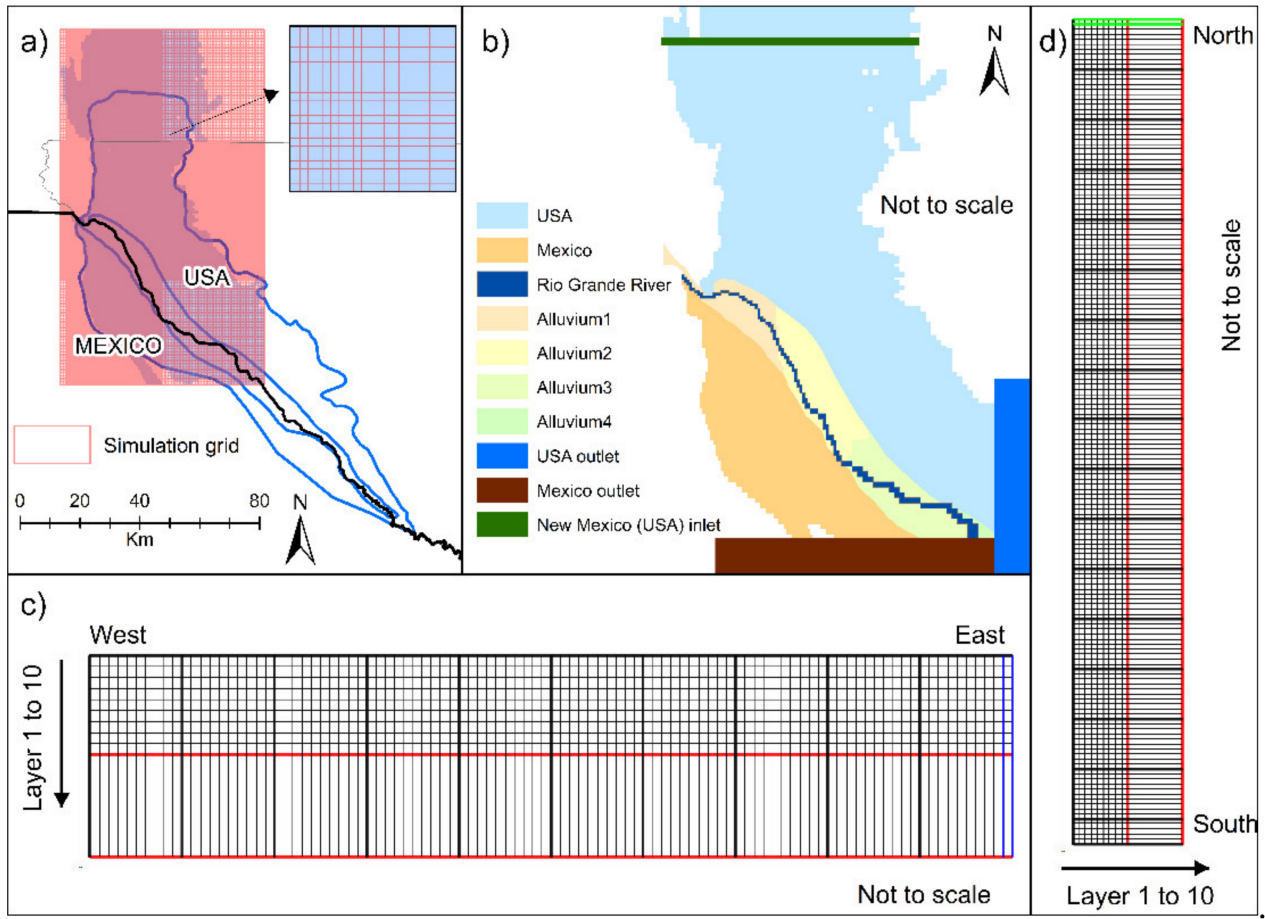

Figure 3. (a) Computational grid consisting of 165 rows and 100 columns. Inset shows a close location highlighting different grid sizes varying from 500 to $1170 \mathrm{~m}$; (b) the location of inflow and outflow boundaries and other features; (c) West to East cross-section showing ten vertical layers; and (d) North to South cross-section showing ten vertical layers. Four alluvium areas were defined based on hydraulic characteristics along the river channel. The red color in (c,d) shows the computation grid's bottommost layer has a different vertical thickness compared to the other nine layers.

\subsubsection{Updated MODFLOW Coupled with a Watershed Model}

It is critical to analyze both the surface water and groundwater on either side of the border. We are developing a coupled watershed-groundwater model to simulate surface and subsurface hydrologic processes [57]. The Soil and Water Assessment Tool (SWAT) will be used as a watershed model that allows a better and fine resolution simulation of the surface water and land use activities. Figure 4a shows the subbasins $(N=69)$ of the SWAT model. The number of hydrologic response units (HRUs) in the SWAT model is 1243 (not shown in Figure). The water balance is maintained at the HRU level. The HRU is the smallest unit for the computation in the SWAT, which is delineated based on a unique combination of soil types, land use/crop type classes, and topography. Figure $4 \mathrm{~b}$ shows the linking of HRUs with the MODFLOW grids and represents linking river cells and SWAT river reach.

Though the SWAT model has its groundwater components, the model itself is lumped [58]. Conversely, the MODFLOW model has challenges in computing the distributed groundwater recharge. The coupled model allows HRU-based groundwater recharge to the MODFLOW model, and grid-based outputs from MODFLOW are sent back to the SWAT model. Similarly, river-aquifer flow exchange and water transfer by pumping occur at the MODFLOW river and pumping cells with the SWAT river reach and HRUS. The exchange happens on a daily scale, and the coupled model is run simultaneously. Details on the coupling are available in Kim et al. [58]. The coupled model assesses flux exchange across the 
border and between different formations using the Zonebudget package [59] that computes the water budget [60]. The SWAT model was set up for the Middle Rio Grande River from San Marcial to Presidio. Detailed hydrologic analyses were performed for Rincon valley, and the details are available in Ahn et al. [61]. The coupled watershed-groundwater model is still under evaluation and will be made available as a separate technical publication.

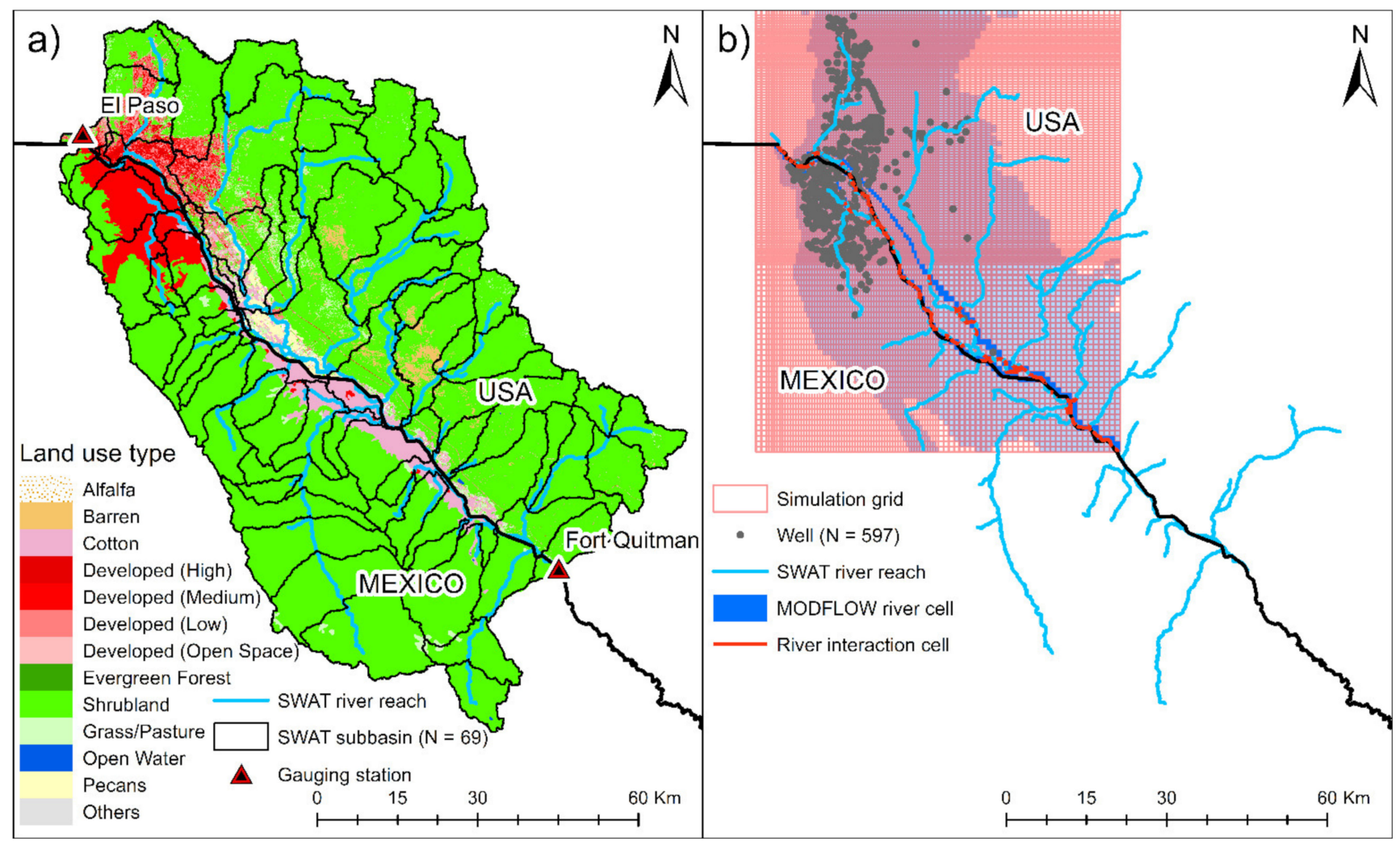

Figure 4. (a) Distribution of subbasins of Soil and Water Assessment Tool (SWAT) model superimposed over the land use type across the study area; (b) the location of wells, and river interactions between SWAT river reach and groundwater (MODFLOW) river cell used for the surface-subsurface linkage.

\subsubsection{Simulation of Solute Transport (Salinity)}

An elevated salinity level has significant environmental and economic impacts on nature as well as agricultural and urban water management. These include agricultural yield reduction, increased water use for salinity leaching, reduced life of water-using appliances and water delivery systems, and increased cost of water use, either by water softening system or dispensed water $[62,63]$. Under the current groundwater depletion scenario, the brackish groundwater will continue to intrude into fresh groundwater and will probably affect well locations more in the future. A few modeling works are available for the Hueco Bolson aquifer [34,35]. We plan to implement a solute transport model into the coupled watershed-groundwater model.

\section{Water Management Efforts and Issues}

In recognizing the continued depletion of fresh groundwater in the aquifer, El Paso and Ciudad Juarez have made efforts to address management issues of shared groundwater resources via cooperation [13]. EPW has reduced its pumping from Hueco Bolson since the mid-1990s, implemented a managed aquifer recharge program to inject reclaimed water, and constructed a desalination plant to utilize brackish groundwater $[13,17,20]$. Ciudad Juarez is considering an alternative source from La Mesilla Bolson/Conejos Medanos aquifer to reduce the stress on Hueco Bolson. The conjunctive management of Hueco Bolson and the Rio Grande is an important part of the water supply of El Paso as both 
contribute approximately $40 \%$ each to the potable water use of EPW in non-drought years [14]. In addition, EPW uses the Mesilla Bolson (17\%) and desalination (5\%) to supply the city with potable water [14]. To secure water supply, the EPW is planning increased use of reclaimed water, desalinated groundwater from more remote parts of the Hueco Bolson, and importing additional water sources from other basins [64]. On the other hand, Ciudad Juarez uses Hueco Bolson as its main source of portable water and uses the Mesilla Bolson/Conejos Medanos aquifer as a complementary source as water is imported via a $40 \mathrm{~km}$ aqueduct [4].

In this section, we highlight issues related to water quantity and quality, climate change impacts, governance and jurisdiction, and the prospect of integrated groundwater management (IGM).

\subsection{Water Quantity and Quality}

Based on the carbon dating of the groundwater samples, Anderholm and Heywood [38] found that groundwater is 12,000 years old near the New Mexico/Texas state line. The Hueco Bolson aquifer has been pumped for its ancient groundwater for over a century, resulting in groundwater decline [8]. The cross-border exchange of both the surface and subsurface water has complicated the understanding of water availability on both sides of the border. The groundwater flow between the USA and Mexico has changed over the past decades depending on which city caused stronger water withdrawal [13,19].

Water quality is a crucial factor that guides the usability of water. Due to the surrounding brackish water, groundwater quantity and quality issues of the Hueco Bolson are strongly interlinked. The rapid groundwater depletion due to heavy groundwater pumping is not only a concern by itself but has also resulted in brackish groundwater intrusion into freshwater sections of the aquifer. The water quality decrease in public wells was so low in the El Paso area that in some cases, well abandonment was required [31]. Due to the inter-basin flow of poor-quality groundwater, freshwater storage depletion will be even faster than that calculated from groundwater pumping only [19].

In 1979, the Texas Water Development Board (TWDB) estimated that the Hueco Bolson could not be used as a freshwater supply as the groundwater body will have slightly saline conditions from brackish groundwater intrusion by 2031 [65]. This scenario was fortuitously prevented as various measures were put in place, including water injection [65]. In addition, the EPW has used reclaimed wastewater to recharge the Hueco Bolson aquifer at its northeast wells since 1985 [18] and the infiltration basin after 2001 [19] to minimize the negative impacts of decreasing groundwater levels. However, to our knowledge, there are no similar operations on the Mexican side of the aquifer. Therefore, technical water management actions on both sides on the border must be implemented to reduce the negative effects of the scarce groundwater and create new quasi-stable conditions of the Hueco Bolson through a bilateral and participatory approach.

\subsection{Impacts of Climate Change}

It is ubiquitous that the entire globe is warming and is being more pronounced by the anthropogenic release of greenhouse gases (GHGs) [66]. Looking at the near-surface temperature of the CRU dataset from 1951 to 2019, we find that the study area already experienced an increase of $1^{\circ} \mathrm{C}$ in annual average temperature between 1951-1990 and 1991-2019. The hydrologic and the water cycle are deeply affected by alterations in climate variables. Surface water and groundwater are affected in one way or another due to shifts in precipitation patterns, intensity, and temperature. Additionally, the Rio Grande receives snowmelt runoff in southern Colorado and northern New Mexico [19], which is anticipated to be affected by changing climate.

Generally, aquifers have high storage capacities and are less sensitive to climate change than surface water bodies. However, the decrease in mountain front recharge (currently very little in the Hueco Bolson) and the temperature rise impact the hydrologic cycle and water availability. In addition, prolonged drought may affect water quantity, deteriorate 
groundwater quality, and stop or reduce groundwater recharge. Therefore, understanding hydrologic processes in aquifer systems is critical to developing adaptive management strategies under changing climates.

\subsection{Governance and Jurisdiction Considerations}

The governance and jurisdiction of common pool groundwater resources are challenging [67]. The issues are compounded by the transboundary nature of the Hueco Bolson. In Texas, the Hueco Bolson is recognized as a major aquifer by the TWDB and one of the major water sources by the Far West Regional Water Planning Group (E), which makes water management recommendations to the TWDB. According to the New Mexico constitution, all water bodies belong to the public, and the State Engineer permits rights under the doctrine of prior appropriation (first in time, first in right) to use the water. Property rights and governance structures related to groundwater resources are principally different within New Mexico and Texas in the USA and the two countries. In Mexico, groundwater rights lie with the Mexican federal authorities. Groundwater governance is centralized under the federal water agency Comision Nacional del Agua (CONAGUA). For surface water and groundwater shared with the USA, there is a common assumption that the de facto authority is with the International Boundary and Water Commission-Mexico Section (CILA) [68].

Within the USA, groundwater rights are juridical issues of each state. In Texas, the landowner owns the groundwater, and the rule of capture, also known as the principle of "the biggest pump", governs the groundwater use [4].The dichotomy in regulations is highlighted by the Texas surface water and groundwater jurisdictions. Surface water is considered to be owned by the people of Texas and allocated for beneficial use according to the doctrine of prior appropriation. Groundwater, however, is governed by the "rule of capture", giving the landowner authority to use/pump as much water as needed without liability to neighbors for drying up their wells. The separate management of groundwater and surface water systems described as hydroschizophrenia is often a key hurdle in solving complicated common pool water system sharing problems [69]. Hydroschizophrenia is compounded by the transboundary nature of the water system [70]. In the case of Hueco, as other authors have suggested (e.g., Hargrove et al. [71]), it can be extended to include the myriad of different regulations that govern the connected surface water and groundwater in three jurisdictions (Texas, New Mexico, and Chihuahua).

There have been water-sharing agreements and treaties to address transboundary water sharing in the region. The Rio Grande Compact [72] is an interstate compact in the USA between the states of Colorado, New Mexico, and Texas, and approved by the United States Congress to equitably apportion the waters of the Rio Grande Basin. Similarly, the international treaties between the USA and Mexico (e.g., 1944 treaty [73]) deal with issues related to boundary water sharing. The 1944 treaty "Utilization of Waters the Colorado and Tijuana Rivers and of the Rio Grande" allocated waters in the international segment of the Rio Grande from Fort Quitman, Texas, to the Gulf of Mexico. This treaty also authorized the two countries to construct, operate and maintain dams on the main channel of the Rio Grande. A recent analysis of transboundary water delivery for compliance with the treaty has demonstrated a delivery regime that is not similar to what was anticipated at the time of signing, largely attributable to changing water use [74]. Uncertainties in the water deliveries, particularly large deficits in some years with low water availability, are a significant problem in water management.

According to Sanchez and Eckstein [42], small-scale, informal, and non-binding approaches seem more viable for future transboundary groundwater management between Mexico and Texas. A holistic approach that captures the opinions of growers, stakeholders, and experts is necessary to address associated socioecological issues. The transboundary water rights can be modeled in the system model by generating different water allocations scenarios. However, binational interests are difficult to define without experts' interpretation of casual chains $[70,75]$. 


\subsection{Integrated Groundwater Management (IGM) for Hueco Bolson}

IGM may be defined as the "structured process that promotes the coordinated management of groundwater and related resources (including conjunctive management with surface water), taking into account non-groundwater policy interactions, in order to achieve balanced economic, social welfare, and ecosystem outcomes over space and time" [76]. Given the transboundary nature, the problem space (referring to issues/domains that must be engaged to solve the problem) for an IGM strategy for Hueco includes several components shown in Figure 5. Any decision support tool and integrated modeling derived for IGM support connections between elements in the problem space. The issues related to water allocation, water scarcity, irrigation, water quality, water supply, diverse jurisdictions, and climate change have been discussed earlier in the paper. JEDI represents justice, equity, diversity, and inclusion in the IGM process [77]. The four components of JEDI applied to water, or environmental systems may be thought of as:

1. Justice-the right to an equitable, safe, healthy, productive, and sustainable environment for all community members;

2. Equity-impartiality and fairness in the procedures, processes, and allocation of resources;

3. Diversity_including a broad demographic mix (including race, age, gender, ethnicity, cultural background, geography) within a group or organization, which reflects the makeup of the community;

4. Inclusion - ability of diverse individuals to participate fully in all aspects, including the decision-making processes.

Given the stakeholder buy-in needed to manage the transboundary common pool resource, it is anticipated that aspects of JEDI, as defined above, become important to develop and successfully apply the management plan.

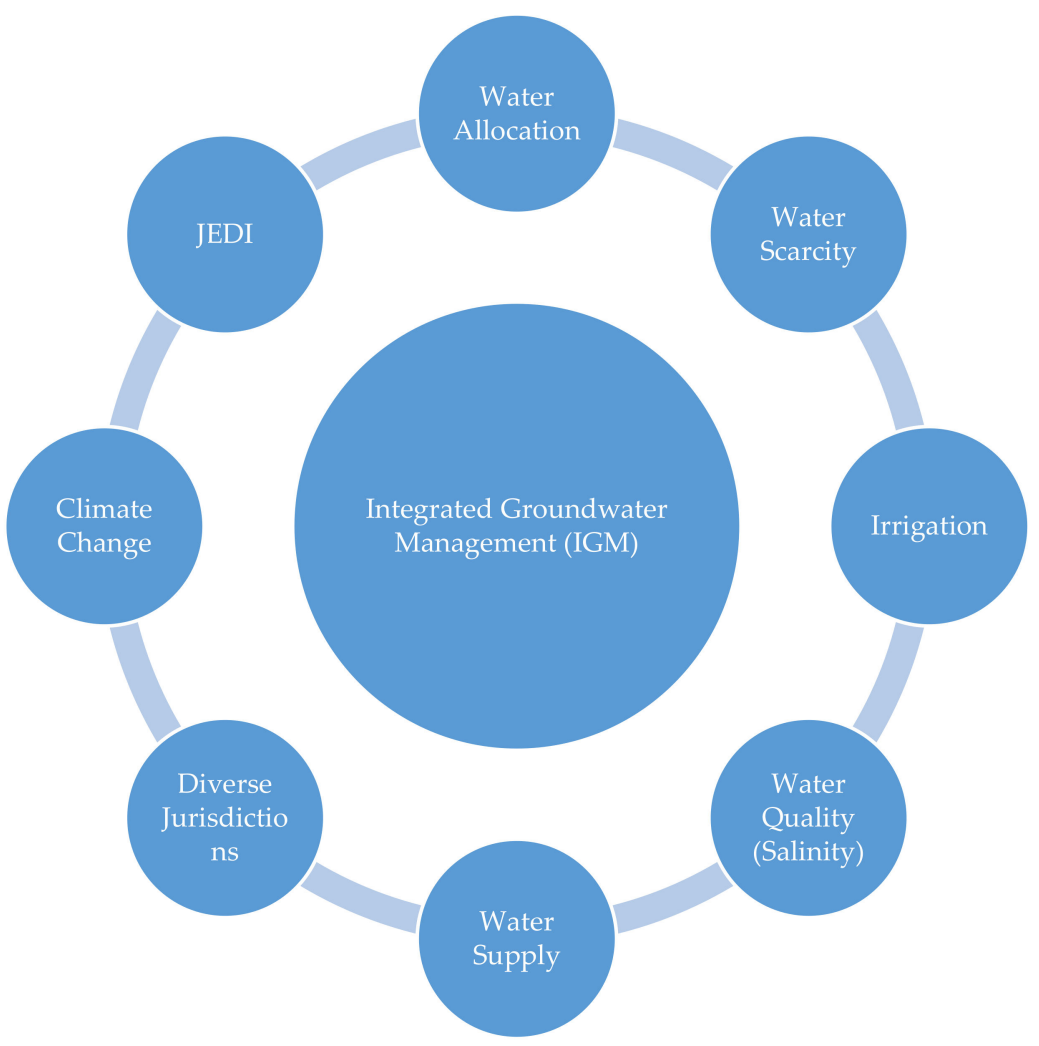

Figure 5. Problem space for integrated groundwater management (IGM). Modeling tools and other decision support tools should address the whole problem space. JEDI is used to represent justice, equity, diversity, and inclusion. 
For Hueco Bolson modeling and planning, given the hydroschizophrenia (discussed above) and the inequities among the communities on two sides of the international border and within each jurisdiction (see McDonald and Grinesiki [78], Grineski and Collins [79], Grineski et al. [80], Moya et al. [81]), JEDI becomes an important consideration. Although environmental justice and equity are key policy objectives in the region [62] and worldwide [82-84], they are seldom considered in knowledge production using models. However, any sustainable and acceptable management solution will need all stakeholders' buy-in and knowledge co-production [85]. Furthermore, centering our science and communication framing around JEDI $[77,86]$ can provide an essential point of access for all communities to engage with scientific communication, preventing critical gaps in stakeholder representation. However, such engagement at scale in different countries remains a challenge.

Nevertheless, the tools developed for IGM should be designed to allow JEDI engagement. From a model development and integration perspective, this design may include more intuitive and straightforward modeling tools that are easier to understand and allow interaction without any computing limitation. Different models in conjunction with existing numerical models, such as the system model, can provide a participatory modeling environment to bring together binational stakeholders and build a collaborative Hueco Bolson model for the transboundary region. Based on the stakeholders' opinions, the Hueco Bolson model can be developed by conceptualizing and quantitatively analyzing alternative management scenarios. The proposed approach aims to bring the scientific community, stakeholders, and decision makers together in developing equitable and inclusive IGM following open science, coordinated, and networked efforts $[87,88]$. We present the future direction in groundwater modeling in the subsequent section.

\section{Future Outlook}

Future work will require a continued collaboration of the two countries and researchers to tackle the various management issues of the transboundary aquifer. To develop an IGM supporting tool for Hueco Bolson, we are trying to develop a system-of-systems (SoS) models supported by the system model and BBN. These models, as planned, will utilize the existing calibrated model (SWAT and MODFLOW) as an "expert" and integrate opinions from other expert stakeholders. Additionally, new insights through additional data and groundwater simulations can be integrated or used as input parameters in the existing numerical model. In this section, we highlight future outlooks based on water data and decision modeling.

\subsection{Protocol for Transboundary Data Sharing and Collection}

The International Boundary \& Water Commission (IBWC) oversees the application of USA-Mexico treaties related to boundary demarcation and the national ownership of water resources [5]. Transboundary Aquifer Assessment Program (TAAP) is a binational scientific effort that enables data sharing, harmonization, and knowledge improvement of the transboundary aquifers. Federal agencies, academic institutions, and research institutes analyze the common data to better understand the groundwater dynamics of transboundary aquifers. The TAAP project plans to develop an interactive and open-data portal, including numerically simulated outcomes. The distribution of input data currently used in existing models is not consistent with the JEDI principles. Due to the ease of water, land use, and other data access in the USA, the USA data dominate and bias the models. In the models, water system processes on the Mexican side are assumed to follow a similar trend as on the USA side (where data are available to calibrate the models), which is an untested and potentially incorrect assumption. Similarly, this data imbalance is also valid across other divides (e.g., urban-rural).

Under the TAAP program, a memorandum of understanding between CILA for Mexico and the Texas Water Research Institute (TWRI) for the USA has been brought on to exchange data between countries and fill data gaps in urban and rural areas in both countries. Additionally, we will estimate agricultural withdrawal by compiling and 
analyzing land use, land cover data, and crop acreage data to help overcome data gaps in the rural areas where data are sometimes scarce. We may also consider using some data for validation instead to balance the data distribution.

\subsection{System Model}

A system model explicitly represents the diverse set of connections within a system, the sensitivity of each link, dynamic mechanism, and feedback loops. The concept of system dynamics was first introduced by Forrester [89] to determine problems and evolve possible solutions by boosting our system thinking capacity to extrapolate and interpolate in a broader sense. The system model formalizes the main causal chains and complex mechanisms in a meaningful manner [90]. The benefit of the system model is that the relationship between the "cause" and "effect" can be easily inferred and simulated by stocks and flows processes. Additionally, it can deal with a high degree of nonlinear problems, which are commonly present in managed environmental systems such as an aquifer [91].

An aquifer is one of the most complex systems consisting of interacting dynamic variables and balancing feedback loops. Many studies in the literature have demonstrated the importance of a system model in managing aquifer systems and their connected subsystems [92]. Recently, Afshar et al. [93] integrated surface water and groundwater into a single cyclic storage system model to simulate a long-term outlook. Barati et al. [94] developed a smart groundwater governance system model introducing an index and four indicators, namely equitability, efficiency, sustainability, and democracy. Balali and Viaggi [95] employed a system model to identify limits to growth and additional risks of aquifer development. Niazi et al. [96] determined the recharge and discharge dynamics within the aquifer system based on the long-term aquifer responses to hydrological variability.

The Hueco Bolson aquifer system model (Figure 6) can act as a mental model that allows stakeholders from Mexico and the USA to agree on a common representation, which creates new insights and unifies the knowledge of different stakeholders, water practitioners, and researchers. Figure 6 shows the connectivity of the surface water system with the groundwater system in the Hueco Bolson. From both Mexico and the USA sides, surface water delivery and groundwater pumping are taking place to meet the regional water demand. Here, water availability depends on the surface water storage in the reservoirs upstream and the amount of water recharged into the Hueco Bolson aquifer. Additionally, lateral flows from the Tularosa basin of the USA add a significant amount of inflows to the Hueco Bolson aquifer system. Therefore, the interaction between the surface water recharge into the aquifer system and managed aquifer recharge by EPW [18,19] and the aquifer water pumping back to the surface for agricultural irrigation $[18,19]$ as per the water demand indicates an important water-balancing feedback loop of the model. This loop could help understand the dynamic nature of the Hueco Bolson aquifer and the change in water fluxes over time.

The collaborative aquifer system model can further simulate the anticipated effects of land-use change, climate change, and human activities on regional water supply and demand and understand their dynamic relationships [90]. Additionally, the system model will help provide insights and alternative opportunities for allocating the aquifer water, policy support, and participatory strategic planning to mitigate future impacts [97-99]. Policy and decision-makers can utilize scenario-based analysis to obtain a set of optimal solutions and trade-offs between transboundary aquifers [100]. The benefits of the system model include the management of the binational aquifer, exploitation of uncontaminated groundwater, control of groundwater fluctuations, conjunctive use of groundwater [101-103], and securing the future water [104]. Although only the water-system model is shown in Figure 6, one can conceive a system-of-systems model that informs decision-makers on the interaction among environment (water and land use), social (population growth rate and anthropogenic activities), economic (water demand, water productivity, and wastewater discharge), and political (policy, decision, and management framework) system. 


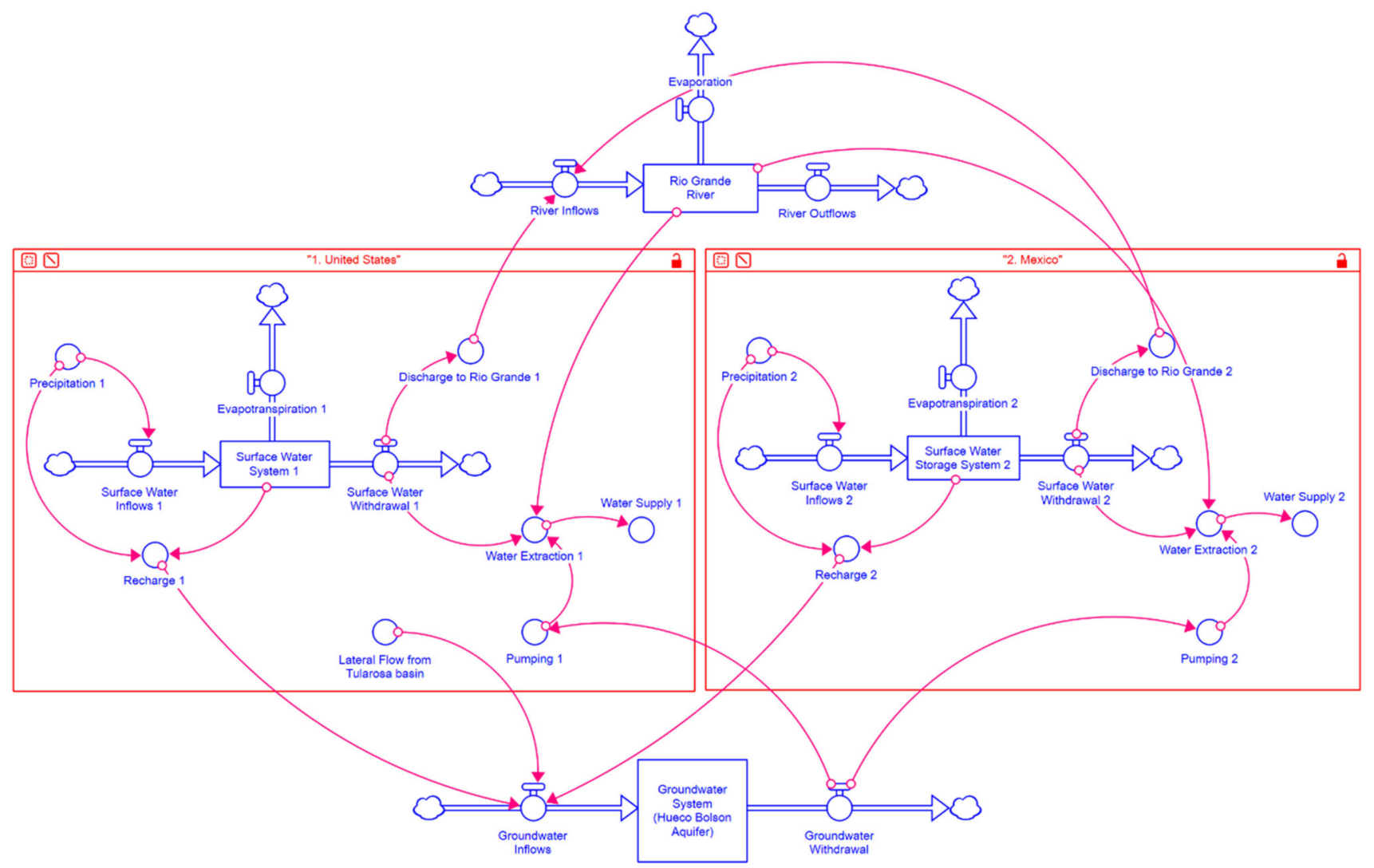

Figure 6. System model concentrating on the water system for a transboundary aquifer-Hueco Bolson.

\subsection{Bayesian Belief Network (BBN)}

The BBN is a graphical model that shows probabilistic relationships between different quantitative and qualitative variables. The BBN can predict and analyze associational relationships, i.e., cause and effect, even if some data entries are missing or/and the precise relationship between variables is unknown [105]. The formalism also allows using a wide range of algorithms to learn the network from data or/and use experts' knowledge for some prior associations. Ground-based and remotely sensed data, numerically simulated outputs, and stakeholders' opinions can be used to generate and learn the model. Integrating knowledge from these different domains makes BBNs a useful tool for problems with a high level of uncertainty and complexity in water management issues [106]. It has been shown that BBNs are well suited as planning tools to incorporate the system view of various stakeholder groups next to numeric data [107]. Furthermore, involving the different expert groups can help overcome the problem of incomplete data and to link variables [108]. Finally, the BBN allows assessing the alteration in conditional probabilities upon the perturbations on any factors.

We aimed to develop a BBN model to understand the surface and sub-surface water dynamics in the Hueco Bolson transboundary aquifer system. Figure 7 shows ongoing efforts to develop the BBN for Hueco Bolson. Different nodes are from various thematic groups, including legislative framework, agriculture, weather and climate, demography, and the economy are acyclically connected. Conditional probabilities for different combinations will be input into the model based on earth observations, ground-based observations, modeled results, experts' knowledge, stakeholders' participation, and legal frameworks. For instance, the land-use transition can be quantified using satellite images and annual crop data layers at high spatial resolution. The legal framework will be based on a county to the state level and will be different for the USA and Mexico. Similarly, demographic data could range from the household, county, etc., to other administrative boundaries. Farmers' 
input can be provided on a farm field level. In BBN modeling, data from several sources will first be transformed into conditional probability based on observations.

Overall, the BBN model will likely consist of a range of variables, including hydroclimate, groundwater, crop types, profit outlook, land use transition, grower risk tolerance, consumption per capita, industrial performance, and population growth. Expert knowledge and data-driven approaches, i.e., different statistical algorithms, are used to learn the relationship between the variables. Like the system model discussed earlier, this model will allow intuition building among stakeholders. However, the key difference is the deeper and more direct integration of expert opinion with BBNs. Thus, these SoS modeling approaches will be helpful to capture the opinion and knowledge from different stakeholders, including growers, academicians, planners, and decision-makers. Incorporating experts knowledge will help build trust in the modeling system. Furthermore, from a technical perspective, it will help overcome some of the anticipated incomplete data problems to drive more physically based models [108].

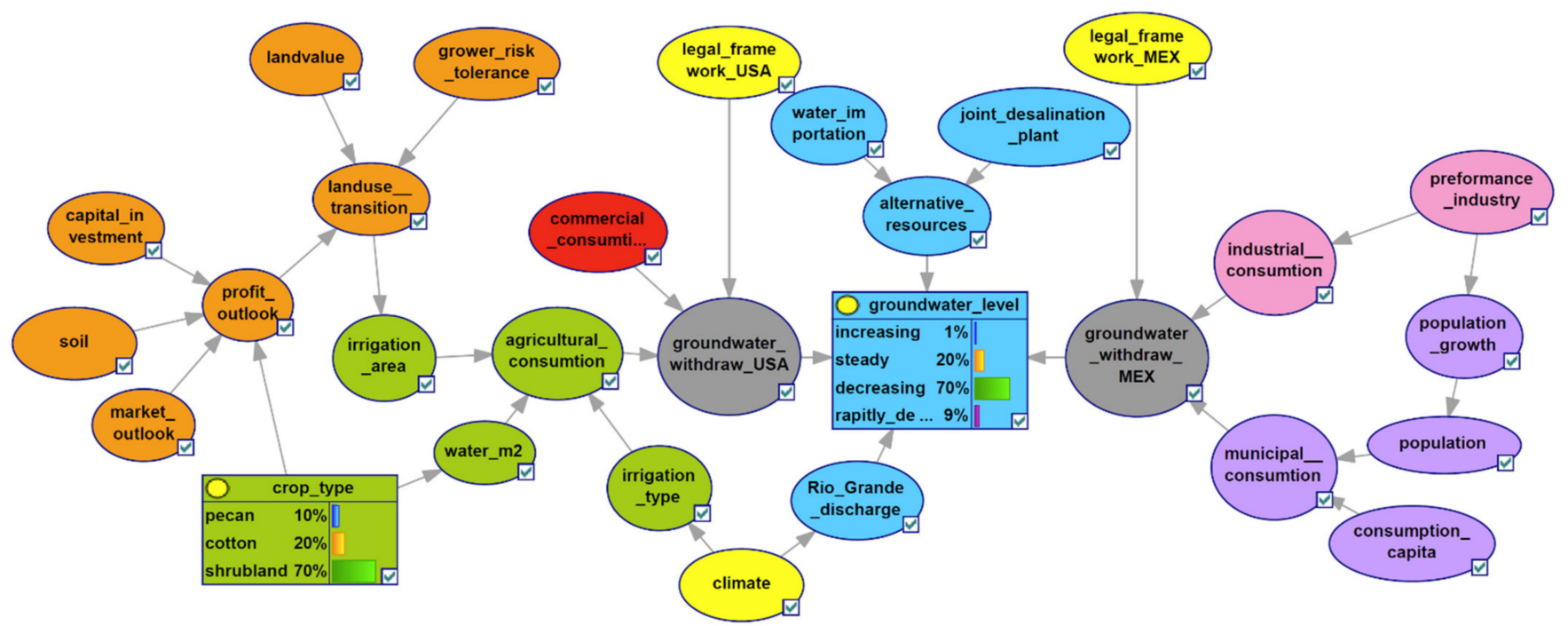

Figure 7. Simplified Bayesian belief network for a transboundary aquifer. Each variable is represented by one node and has an accompanying conditional probability table.

\section{Conclusions}

This paper highlights the current status and future works in the water system management for the transboundary Hueco Bolson aquifer between the USA and Mexico. The challenges involved in managing a transboundary aquifer are of a technical, social, political, and juridical nature, including groundwater withdrawal, brackish groundwater intrusion, multi-discipline multi-stakeholders participation, centralized or/and decentralized governance structures, different jurisdictions. Therefore, around the core of groundwater science, it is important to integrate other disciplines. The first step for Hueco Bolson has been to establish a recognition of both countries and all counties that share the groundwater body. The next step (ongoing) is to cooperate for transboundary data sharing and use the data to modify and improve the models. Finally, it is critical that models are developed in support of IGM with JEDI principles. Data for modeling groundwater not only means the traditionally recorded observations but also includes remotely sensed data, stakeholder engagement, and expert knowledge. These data can help solve the problems and challenges related to the aquifer using an integrated SoS approach along with physically based numerical simulations. 
Author Contributions: Conceptualization, R.T. and S.K.; methodology, R.T.; software, R.T., H.M. and S.S.P.; validation, R.T., S.K., R.S. and Z.S.; formal analysis, R.T., H.M. and S.S.P.; investigation, R.T. and H.M.; resources, R.S. and S.K.; data curation, R.T. and H.M.; writing-original draft preparation, R.T. and H.M.; writing-review and editing, R.T., H.M., S.S.P., R.S. and Z.S.; visualization, R.T.; supervision, S.K. and R.S.; project administration, R.S. and S.K.; funding acquisition, R.S. and S.K. All authors have read and agreed to the published version of the manuscript.

Funding: This research was funded by the United States Geological Survey (USGS) under the Transboundary Aquifer Assessment Project (TAAP): USGS Project No. G17AC00440 and United States Department of Agriculture (USDA) NIFA Hatch project 1022633.

Institutional Review Board Statement: Not applicable.

Informed Consent Statement: Not applicable.

Data Availability Statement: Data used in the study will be provided on request.

Acknowledgments: The authors are grateful to the United States Geological Survey (USGS) and the United States Department of Agriculture (USDA) for financial support.

Conflicts of Interest: The authors declare no conflict of interest.

\section{References}

1. Fitzmaurice, M. Convention on Law of the Non-Navigational Uses of International Watercourses. Leiden J. Int. Law 1997, 10, 501-508. [CrossRef]

2. Eckstein, G. Implications of the UN Watercourses Convention for Groundwater Resources. International Water Law Project Blog. 2014. Available online: https:/ / www.internationalwaterlaw.org/blog/2014/08/05/professor-gabriel-eckstein-implicationsof-the-un-watercourses-convention-for-groundwater-resources/ (accessed on 13 April 2021).

3. Sanchez, R.; Lopez, V.; Eckstein, G. Identifying and Characterizing Transboundary Aquifers along the Mexico-US Border: An Initial Assessment. J. Hydrol. 2016, 535, 101-119. [CrossRef]

4. Sanchez, R.; Eckstein, G. Aquifers Shared Between Mexico and the United States: Management Perspectives and Their Transboundary Nature. Groundwater 2017, 55, 495-505. [CrossRef] [PubMed]

5. Tapia-Villaseñor, E.M.; Megdal, S.B. The US-Mexico Transboundary Aquifer Assessment Program as a Model for Transborder Groundwater Collaboration. Water 2021, 13, 530. [CrossRef]

6. Slichter, C.S. Observations on the Ground Waters of the Rio Grande Valley; Water-Supply Paper 141; US Geological Suvey: Reston, VA, USA, 1905; p. 93.

7. Richardson, G.B. El Paso Folio, Texas; Atlas of the United States No. 166; US Geological Survey: Reston, VA, USA, 1909.

8. White, D.E. Summary of Hydrologic Information in the El Paso, Texas, Area, with Emphasis on Ground-Water Studies, 1908-1980; Texas Water Development Board: Austin, TX, USA, 1987; p. 75.

9. Sayre, A.N.; Livingston, P.P. Ground-Water Resources of the El Paso Area, Texas; Water Supply Paper; US Government Printing Office: Washington, DC, USA, 1945; Volume 919.

10. Knowles, D.B.; Kennedy, R.A. Ground-Water Resources of the Hueco Bolson, Northeast of El Paso, Texas; US Government Printing Office: Washington, DC, USA, 1958.

11. INEGI Censo Población y Vivienda. 2020. Available online: https://www.inegi.org.mx/programas/ccpv/2020/default.html\# Tabulados (accessed on 19 April 2021).

12. United States Census Bureau. US Census Bureau QuickFacts: El Paso City, Texas. Available online: https://www.census.gov/ quickfacts/elpasocitytexas (accessed on 19 April 2021).

13. Sheng, Z.; Devere, J. Understanding and Managing the Stressed Mexico-USA Transboundary Hueco Bolson Aquifer in the El Paso Del Norte Region as a Complex System. Hydrogeol. J. 2005, 13, 813-825. [CrossRef]

14. El Paso Water Utilities Water Resources. Available online: https://www.epwater.org/our_water/water_resources (accessed on 21 April 2021).

15. Sheng, Z.; Michelsen, A.; Fahy, M.P.; Ashworth, J. Conflicts and Cooperation: Water Resources Planning in Far West Texas. In Proceedings of the World Water \& Environmental Resources Congress 2003, Philadelphia, PA, USA, 23-26 June 2003; American Society of Civil Engineers: Philadelphia, PA, USA; pp. 1-10.

16. Zhuping, S.; Mace, R.E.; Fahy, M.P. The Hueco Bolson: An Aquifer at the Crossroads. In Aquifers of West Texas; Texas Water Development Board: Austin, TX, USA, 2001.

17. Hibbs, B.J.; Boghici, R.N.; Hayes, M.E.; Ashworth, J.B.; Hanson, A.T.; Samani, Z.A.; Kennedy, J.F.; Creel, B.J. Transboundary Aquifers of the El Paso/Ciudad Juarez/Las Cruces Region-Chapter 4 Southeastern Hueco Aquifer; Texas Water Development Board and New Mexico Water Resources Research Institute Report; US Environmental Protection Agency: Dallas, TX, USA, 1997.

18. Sheng, Z. An Aquifer Storage and Recovery System with Reclaimed Wastewater to Preserve Native Groundwater Resources in El Paso, Texas. J. Environ. Manag. 2005, 75, 367-377. [CrossRef] 
19. Sheng, Z. Impacts of Groundwater Pumping and Climate Variability on Groundwater Availability in the Rio Grande Basin. Ecosphere 2013, 4, art5. [CrossRef]

20. Eastoe, C.J.; Olivas, A.G.; Hibbs, B.J. Tracers of Groundwater Mixing in the Hueco Bolson Aquifer, Ciudad Juárez, Mexico. J. Environ. Eng. Geosci. 2016, 22, 195-207. [CrossRef]

21. Capt, T.; Mirchi, A.; Kumar, S.; Walker, W.S. Urban Water Demand: Statistical Optimization Approach to Modeling Daily Demand. J. Water Resour. Plan. Manag. 2021, 147, 04020105. [CrossRef]

22. Davis, M.E.; Leggat, E.R. Preliminary Results of the Investigation of the Saline-Water Resources in the Hueco Bolson near El Paso, Texas; US Geological Survey: Reston, VA, USA, 1967.

23. Bredehoeft, J.D.; Pinder, G.F. Digital Analysis of Areal Flow in Multiaquifer Groundwater Systems: A Quasi Three-Dimensional Model. Water Resour. Res. 1970, 6, 883-888. [CrossRef]

24. Meyer, W.R. Digital Model for Simulated Effects of Ground-Water Pumping in the Hueco Bolson, EL Paso Area, Texas, New Mexico and Mexico; US Geological Survey: Reston, VA, USA, 1976; p. 36.

25. Wilson, L. Report 3-Hydrogeology of the Hueco Basin: Prepared for the Public Services Board; City of El Paso, Texas; Lee Wilson \& Associates Inc.: Santa Fe, NM, USA, 1985.

26. Kernodle, J.M. Summary of US Geological Survey Ground-Water-Flow Models of Basin-Fill Aquifers in the Southwest Alluvial Basins Region, Colorado, New Mexico, and Texas; Open-File Report; US Geological Survey: Reston, VA, USA, 1992.

27. McDonald, M.G.; Harbaugh, A.W. A Modular Three-Dimensional Finite-Difference Ground-Water Flow Model; US Geological Survey: Reston, VA, USA, 1988.

28. Kipp, K.L. HST3D: A Computer Code for Simulation of Heat and Solute Transport in Three-Dimensional Ground-Water Flow Systems; US Geological Survey: Reston, VA, USA, 1987.

29. Groschen, G.E. Sumulation of Ground-Water Flow and the Movement of Saline Water in the Hueco Bolson Aquifer, El Paso, Texas, and Adjacent Areas; Open-File Report; US Geological Survey: Reston, VA, USA, 1994.

30. Harbaugh, A.W.; McDonald, M.G. User's Documentation for MODFLOW-96, an Update to the US Geological Survey Modular Finite-Difference Ground-Water Flow Model; Open-File Report; US Geological Survey: Reston, VA, USA, 1996.

31. Heywood, C.E.; Yager, R.M. Simulated Ground-Water Flow in the Hueco Bolson, an Alluvial-Basin Aquifer System near El Paso, Texas; US Department of the Interior, US Geological Survey: Reston, VA, USA, 2003.

32. Hutchison, W.R. Hueco Bolson Groundwater Conditions and Management in the El Paso Area; EPWU Hydrogeology Report 04-01; El Paso Water-Publich Service Board: El Paso, TX, USA, 2004.

33. Papadopoulos, S.S. Groundwater Flow for Administration and Management in the Lower Rio Grande Basin; Main Report; Technical Report Prepared for the State of New Mexico; New Mexico State Engineer: Santa Fe, NM, USA, 2007.

34. Hutchison, W.R.; Montgomery \& Associates. Groundwater Flow and Transport Model for Hueco Bolson Aquifer; Report; El Paso Water-Publich Service Board: El Paso, TX, USA, 2016; Volume 1.

35. Hutchison, W.R.; Montgomery \& Associates. Groundwater Flow and Transport Model for Hueco Bolson Aquifer; Appendices; El Paso Water-Publich Service Board: El Paso, TX, USA, 2016; Volume 2.

36. Eastoe, C.J.; Hutchison, W.R.; Hibbs, B.J.; Hawley, J.; Hogan, J.F. Interaction of a River with an Alluvial Basin Aquifer: Stable Isotopes, Salinity and Water Budgets. J. Hydrol. 2010, 395, 67-78. [CrossRef]

37. Eastoe, C.J.; Hibbs, B.J.; Olivas, A.G.; Hogan, J.F.; Hawley, J.; Hutchison, W.R. Isotopes in the Hueco Bolson Aquifer, Texas (USA) and Chihuahua (Mexico): Local and General Implications for Recharge Sources in Alluvial Basins. Hydrogeol. J. 2008, 16, 737-747. [CrossRef]

38. Anderholm, S.K.; Heywood, C.E. Chemistry and Age of Ground Water in the Southwestern Hueco Bolson, New Mexico and Texas; US Geological Survey: Reston, VA, USA, 2003.

39. Budhathoki, P.; Doser, D.I.; Thapalia, A.; Langford, R.P.; Avila, V.M. Geological and Geophysical Studies of the Structure and Stratigraphy of the Northwestern Hueco Bolson Aquifer, El Paso, Texas. Geosphere 2018, 14, 731-748. [CrossRef]

40. Ging, P.B.; Humberson, D.G.; Ikard, S.J. Geochemical Assessment of the Hueco Bolson, New Mexico and Texas, 2016-2017; US Geological Survey: Reston, VA, USA, 2020.

41. Sanchez, R.; Rodriguez, L.; Tortajada, C. Effective Transboundary Aquifer Areas: An Approach for Transboundary Groundwater Management. J. Am. Water Resour. Assoc. 2020, 56, 360-378. [CrossRef]

42. Sanchez, R.; Eckstein, G. Groundwater Management in the Borderlands of Mexico and Texas: The Beauty of the Unknown, the Negligence of the Present, and the Way Forward. Water Resour. Res. 2020, 56, 1-20. [CrossRef]

43. Harris, I.; Osborn, T.J.; Jones, P.; Lister, D. Version 4 of the CRU TS Monthly High-Resolution Gridded Multivariate Climate Dataset. Sci. Data 2020, 7, 109. [CrossRef]

44. Druhan, J.L.; Hogan, J.F.; Eastoe, C.J.; Hibbs, B.J.; Hutchison, W.R. Hydrogeologic Controls on Groundwater Recharge and Salinization: A Geochemical Analysis of the Northern Hueco Bolson Aquifer, Texas, USA. Hydrogeol. J. 2008, 16, 281-296. [CrossRef]

45. Mann, H.B. Nonparametric Tests Against Trend. Econometrica 1945, 13, 245. [CrossRef]

46. Kendall, M. Rank Correlation Methods; Charles Griffin: London, UK, 1975; p. 202.

47. Theil, H. A Rank-Invariant Method of Linear and Polynomial Regression Analysis. In Henri Theil's Contributions to Economics and Econometrics; Raj, B., Koerts, J., Eds.; Advanced Studies in Theoretical and Applied Econometrics; Springer: Dordrecht, The Netherlands, 1992; Volume 23, pp. 345-381, ISBN 978-94-010-5124-8. 
48. Sen, P.K. Estimates of the Regression Coefficient Based on Kendall's Tau. J. Am. Stat. Assoc. 1968, 63, 1379-1389. [CrossRef]

49. Hussain, M.; Mahmud, I. PyMannKendall: A Python Package for Non Parametric Mann Kendall Family of Trend Tests. JOSS J. Open Source Softw. 2019, 4, 1556. [CrossRef]

50. Yue, S.; Wang, C.Y. Applicability of Prewhitening to Eliminate the Influence of Serial Correlation on the Mann-Kendall Test: Technical Note. Water Resour. Res. 2002, 38, 4-1. [CrossRef]

51. Talchabhadel, R.; Karki, R.; Thapa, B.R.; Maharjan, M.; Parajuli, B. Spatio-Temporal Variability of Extreme Precipitation in Nepal. Int. J. Climatol. 2018, 38, 4296-4313. [CrossRef]

52. Ashworth, J.B. Evaluation of Ground-Water Resources in EI Paso County, Texas; Texas Water Development Board: Austin, TX, USA, 1990; p. 33.

53. Harbaugh, A.W. MODFLOW-2005, the US Geological Survey Modular Groundwater Model-The Groundwater Flow Process; Techniques and Methods 6-A16; US Geological Survey: Reston, VA, USA, 2005.

54. Hutchison, W.R.; Hibbs, B.J. Ground Water Budget Analysis and Cross-Formational Leakage in an Arid Basin. Groundwater 2008, 46, 384-395. [CrossRef] [PubMed]

55. Harbaugh, A.W. MF2KtoMF05UC, a Program to Convert MODFLOW-2000 Files to MODFLOW-2005 and UCODE_2005 Files; US Geological Survey: Reston, VA, USA, 2007.

56. Harbaugh, A.W.; Banta, E.R.; Hill, M.C.; McDonald, M.G. MODFLOW-2000, The US Geological Survey Modular Ground-Water Model-User Guide to Modularization Concepts and the Ground-Water Flow Process; Open-File Report; US Geological Survey: Reston, VA, USA, 2000.

57. Ahn, S.; Sheng, Z.; Jung, C.; Park, S.; Bailey, R.; Granados-Olivas, A.; Mirchi, A.; Samimi, M.; Hargrove, W.L. Coupled SWATMODFLOW Modeling for Determining Groundwater Sustainability Under Climate and Pumping Scenarios in a Semi-Arid Agricultural Watershed. In Proceedings of the AGU Fall Meeting, San Francisco, CA, USA, 9-13 December 2019.

58. Kim, N.W.; Chung, I.M.; Won, Y.S.; Arnold, J.G. Development and Application of the Integrated SWAT-MODFLOW Model. J. Hydrol. 2008, 356, 1-16. [CrossRef]

59. Harbaugh, A.W. A Computer Program for Calculating Subregional Water Budgets Using Results from the US Geological Survey Modular Three-Dimensional Finite-Difference Ground-Water Flow Model; Open-File Report; US Geological Survey: Reston, VA, USA, 1990.

60. Sheng, Z.; Jung, C.; Ahn, S.; Sanchez, R.; Tracy, J. Cross-Border Groundwater Movement Affecting Aquifer Storage Depletion in the Hueco Bolson. In Proceedings of the AGU Fall Meeting, San Francisco, CA, USA, 9-13 December 2019.

61. Ahn, S.; Abudu, S.; Sheng, Z.; Mirchi, A. Hydrologic Impacts of Drought-Adaptive Agricultural Water Management in a Semi-Arid River Basin: Case of Rincon Valley, New Mexico. Agric. Water Manag. 2018, 209, 206-218. [CrossRef]

62. Pitman, M.G.; Läuchli, A. Global Impact of Salinity and Agricultural Ecosystems. In Salinity: Environment-Plants-Molecules; Läuchli, A., Lüttge, U., Eds.; Springer: Dordrecht, The Netherlands, 2002; pp. 3-20, ISBN 978-0-306-48155-0.

63. Cooley, H.; Phurisamban, R.; Gleick, P. The Cost of Alternative Urban Water Supply and Efficiency Options in California. Environ. Res. Commun. 2019, 1, 042001. [CrossRef]

64. Texas Water Development Board (TWDB). 2007 State Water Plan-Chapter 2-Region E; Texas Water Development Board: Austin, TX, USA, 2007.

65. Muller, D.A.; Price, R.D. Ground-Water Availability in Texas, Estimates and Projections through 2030; Report 238; Texas Department of Water Resources: Austin, TX, USA, 1979; p. 73.

66. Xu, Y.; Ramanathan, V.; Victor, D.G. Global Warming Will Happen Faster than We Think. Nature 2018, 564, 30-32. [CrossRef] [PubMed]

67. Petersen-Perlman, J.; Megdal, S.; Gerlak, A.; Wireman, M.; Zuniga-Teran, A.; Varady, R. Critical Issues Affecting Groundwater Quality Governance and Management in the United States. Water 2018, 10, 735. [CrossRef]

68. Sanchez, R.; Eckstein, G. The Path towards Groundwater Management in the Borderlands of Mexico and Texas. Wiley Interdiscip. Rev. Water 2020, 7, e1399. [CrossRef]

69. Llamas, M.R.; Martínez-Santos, P. Intensive Groundwater Use: Silent Revolution and Potential Source of Social Conflicts. J. Water Resour. Plan. Manag. 2005, 131, 5. [CrossRef]

70. Jarvis, T.; Giordano, M.; Puri, S.; Matsumoto, K.; Wolf, A. International Borders, Ground Water Flow, and Hydroschizophrenia. Groundwater 2005, 43, 764-770. [CrossRef]

71. Hargrove, W.L.; Sheng, Z.; Granados, A.; Heyman, J.M.; Mubako, S.T. Impacts of Urbanization and Intensification of Agriculture on Transboundary Aquifers: A Case Study. J. Am. Water Resour. Assoc. 2021, 57, 170-185. [CrossRef]

72. Rio Grande Compact Commission Report. Available online: Https://Www.Usbr.Gov/Uc/Albuq/Water/RioGrande/Pdf/Rio_ Grande_Compact.Pdf (accessed on 15 September 2021).

73. Utilization of Waters of the Colorado and Tijuana Rivers and of the Rio Grande, Treaty between the United States of America and Mexico. Available online: https:/ /Www.Ibwc.Gov / Files/1944Treaty.Pdf (accessed on 15 September 2021).

74. Sandoval-Solis, S.; McKinney, D.C. Risk Analysis of the 1944 Treaty between the United States and Mexico for the Rio Grande/Bravo Basin. In Proceedings of the World Environmental and Water Resources Congress 2011, Palm Springs, CA, USA, 22-26 May 2011; American Society of Civil Engineers: Palm Springs, CA, USA, 2011; pp. 1924-1933.

75. Eckstein, G.; Eckstein, Y. A Hydrogeological Approach to Transboundary Ground Water Resources and International Law. Am. Univ. J. Int. Law Rev. 2003, 19, 201-258. 
76. Jakeman, A.J.; Barreteau, O.; Hunt, R.J.; Rinaudo, J.-D.; Ross, A.; Arshad, M.; Hamilton, S. Integrated Groundwater Management: An Overview of Concepts and Challenges. In Integrated Groundwater Management: Concepts, Approaches and Challenges; Jakeman, A.J., Barreteau, O., Hunt, R.J., Rinaudo, J.-D., Ross, A., Eds.; Springer International Publishing: Cham, Switzerland, 2016; pp. 3-20, ISBN 978-3-319-23576-9.

77. The JEDI Collaborative. The Path Forward to Systematic Change Justice. Equity. Diversity. Inclusion. Available online: https: / /jedicollaborative.com/ (accessed on 1 October 2021).

78. McDonald, Y.J.; Grineski, S.E. Disparities in Access to Residential Plumbing: A Binational Comparison of Environmental Injustice in El Paso and Ciudad Juárez. Popul. Environ. 2012, 34, 194-216. [CrossRef]

79. Grineski, S.E.; Collins, T.W. Environmental Injustices in Transnational Context: Urbanization and Industrial Hazards in El Paso/Ciudad Juárez. Environ. Plan. A 2010, 42, 1308-1327. [CrossRef]

80. Grineski, S.E.; Collins, T.W.; Ford, P.; Fitzgerald, R.; Aldouri, R.; Velázquez-Angulo, G.; de Lourdes Romo Aguilar, M.; Lu, D. Climate Change and Environmental Injustice in a Bi-National Context. Appl. Geogr. 2012, 33, 25-35. [CrossRef]

81. Moya, E.M.; Chávez-Baray, S.M.; Wood, W.W.; Martinez, O. Nuestra Casa: An Advocacy Initiative to Reduce Inequalities and Tuberculosis along the US-Mexico Border. Int. Public Health J. 2016, 8, 107-119.

82. Brulle, R.J.; Pellow, D.N. Environmental Justice: Human Health and Environmental Inequalities. Annu. Rev. Public Health 2006, 27, 103-124. [CrossRef]

83. Teron, L. A Language of (In)Justice: Expanding the Sustainability Planning Lexicon. Environ. Justice 2015, 8, 221-226. [CrossRef]

84. Martinez-Alier, J.; Temper, L.; Del Bene, D.; Scheidel, A. Is There a Global Environmental Justice Movement? J. Peasant Stud. 2016, 43, 731-755. [CrossRef]

85. Aaltonen, K. Project Stakeholder Analysis as an Environmental Interpretation Process. Int. J. Proj. Manag. 2011, $29,165-183$. [CrossRef]

86. Taylor, G. Justice, Equity, Diversity, Inclusion (JEDI): Part 1 (The What and Why of JEDI). Available online: https://www. americantrails.org/resources/justice-equity-diversity-inclusion-jedi-part-1-the-what-and-why-of-jedi (accessed on 5 July 2021).

87. Goldman, A.; Emani, S.; Perez-Angel, L.; Rodriguez-Ramos, J.; Stegen, J.; Fox, P. Special Collection on Open Collaboration Across Geosciences. Eos, 6 January 2021; p. 102. [CrossRef]

88. Sharma, S.; Dahal, K.; Nava, L.; Gouli, M.R.; Talchabhadel, R.; Panthi, J.; Roy, T.; Ghimire, G.R. Natural Hazards Perspectives on Integrated, Coordinated, Open, Networked (ICON) Science. Available online: https://www.essoar.org/doi/10.1002/essoar.1050 8384.1 (accessed on 25 October 2021).

89. Forrester, J.W. Urban Dynamics; MIT Press: Cambridge, MA, USA, 1969.

90. Valderrama, J.M.; Ibáñez, J.; Alcalá, F.J.; Dominguez, A.; Yassin, M.; Puigdefábregas, J. The Use of a Hydrological-Economic Model to Assess Sustainability in Groundwater-Dependent Agriculture in Drylands. J. Hydrol. 2011, 402, 80-91. [CrossRef]

91. Ringleb, J.; Sallwey, J.; Stefan, C. Assessment of Managed Aquifer Recharge through Modeling-A Review. Water 2016, 8, 579. [CrossRef]

92. Phan, T.D.; Bertone, E.; Stewart, R.A. Critical Review of System Dynamics Modelling Applications for Water Resources Planning and Management. Clean. Environ. Syst. 2021, 2, 100031. [CrossRef]

93. Afshar, A.; Khosravi, M.; Ostadrahimi, L.; Afshar, A. Reliability-Based Multi-Objective Optimum Design of Nonlinear Conjunctive Use Problem; Cyclic Storage System Approach. J. Hydrol. 2020, 588, 125109. [CrossRef]

94. Barati, A.A.; Azadi, H.; Scheffran, J. A System Dynamics Model of Smart Groundwater Governance. Agric. Water Manag. 2019, 221, 502-518. [CrossRef]

95. Balali, H.; Viaggi, D. Applying a System Dynamics Approach for Modeling Groundwater Dynamics to Depletion under Different Economical and Climate Change Scenarios. Water 2015, 7, 5258-5271. [CrossRef]

96. Niazi, A.; Prasher, S.; Adamowski, J.; Gleeson, T. A System Dynamics Model to Conserve Arid Region Water Resources through Aquifer Storage and Recovery in Conjunction with a Dam. Water 2014, 6, 2300-2321. [CrossRef]

97. Ryu, J.H.; Contor, B.; Johnson, G.; Allen, R.; Tracy, J. System Dynamics to Sustainable Water Resources Management in the Eastern Snake Plain Aquifer Under Water Supply Uncertainty. JAWRA J. Am. Water Resour. Assoc. 2012, 48, 1204-1220. [CrossRef]

98. Mashaly, A.F.; Fernald, A.G. Identifying Capabilities and Potentials of System Dynamics in Hydrology and Water Resources as a Promising Modeling Approach for Water Management. Water 2020, 12, 1432. [CrossRef]

99. Nozari, H.; Moradi, P.; Godarzi, E. Simulation and Optimization of Control System Operation and Surface Water Allocation Based on System Dynamics Modeling. J. Hydroinform. 2021, 23, 211-230. [CrossRef]

100. Andricevic, R.; Kitanidis, P.K. Optimization of the Pumping Schedule in Aquifer Remediation under Uncertainty. Water Resour. Res. 1990, 26, 875-885. [CrossRef]

101. Safavi, H.R.; Enteshari, S. Conjunctive Use of Surface and Ground Water Resources Using the Ant System Optimization. Agric. Water Manag. 2016, 173, 23-34. [CrossRef]

102. Ghasemi, A.; Saghafian, B.; Golian, S. System Dynamics Approach for Simulating Water Resources of an Urban Water System with Emphasis on Sustainability of Groundwater. Environ. Earth Sci 2017, 76, 637. [CrossRef]

103. Madioune, D.H.; Diaw, M.; Mall, I.; Orban, P.; Faye, S.; Dassargues, A. Hydrogeological Characterization and Hydrodynamic Behaviour of the Overexploited Diass Aquifer System (Senegal) Inferred from Long Term Groundwater Level Monitoring. Am. J. Water Resour. 2020, 8, 104-117. 
104. Ratna, D.; Puji, A. Using System Dynamic Modeling for Improving Water Security in the Coastal Area: A Literature Review. Open Access Maced. J. Med. Sci. 2020, 8, 143-154. [CrossRef]

105. Heckerman, D. A Tutorial on Learning with Bayesian Networks. In Innovations in Bayesian Networks; Holmes, D.E., Jain, L.C., Eds.; Studies in Computational Intelligence; Springer: Berlin/Heidelberg, Germany, 2008; Volume 156, pp. 33-82, ISBN 978-3-54085065-6.

106. Phan, T.D.; Smart, J.C.R.; Capon, S.J.; Hadwen, W.L.; Sahin, O. Applications of Bayesian Belief Networks in Water Resource Management: A Systematic Review. Environ. Model. Softw. 2016, 85, 98-111. [CrossRef]

107. Singto, C.; Fleskens, L.; Vos, J.; Quinn, C. Applying Bayesian Belief Networks (BBNs) with Stakeholders to Explore and Codesign Options for Water Resource Interventions. Sustain. Water Resour. Manag. 2020, 6, 23. [CrossRef]

108. Bertone, E.; Sahin, O.; Richards, R.; Roiko, A. Extreme Events, Water Quality and Health: A Participatory Bayesian Risk Assessment Tool for Managers of Reservoirs. J. Clean. Prod. 2016, 135, 657-667. [CrossRef] 